\title{
Pathophysiology of Food Allergy
}

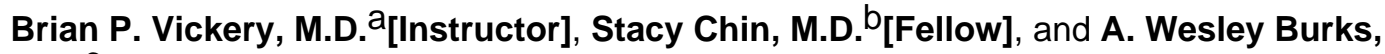 \\ M.D. '[Kiser-Arena Professor of Pediatrics]

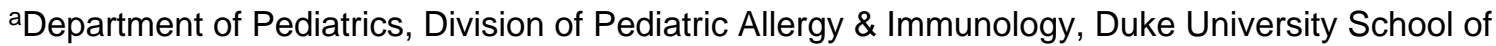 \\ Medicine, Durham NC USA

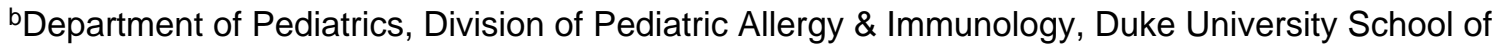 \\ Medicine, Durham NC USA \\ 'Duke University School of Medicine, Durham NC USA; and Chief, Division of Pediatric Allergy \& \\ Immunology
}

\section{Keywords}

Food allergy; IgE; allergic sensitization; dendritic cells; pathophysiology

\section{INTRODUCTION}

Food allergy, which is hypothesized to result from a defect in oral tolerance, is a common, serious, and growing problem in developed countries. Whereas the immune system of all individuals recognize food antigens as foreign, patients with food allergy develop pathological immune responses to these antigens and can rapidly experience harmful adverse symptoms upon re-exposure. Although a recent meta-analysis identified variation in prevalence rates (1), recent survey data from the Centers for Disease Control and Prevention indicate that the current prevalence of food allergy in U.S. children is approximately $4 \%$, an increase of almost $20 \%$ in the last decade (2). Increases in food allergy prevalence have also been observed in methodologically rigorous birth cohort studies which use precise sampling techniques and well-defined outcome measures, suggesting that rising prevalence is not simply due to self-diagnosis or increased recognition of the disorder (3). Similar trends in the prevalence of asthma, allergic rhinitis, and atopic dermatitis support the general concept that atopic diseases are increasingly common (4).

Spontaneous clinical tolerance does develop in some food-allergic individuals and tends to occur in allergen-specific patterns. For example, resolution of allergy to egg, milk, wheat, and soy can generally be expected, although this may take longer than previously appreciated. In contrast, most patients allergic to peanut, tree nuts, and seafood will not outgrow their disease and must maintain strict elimination diets. The natural history of allergy to other important proteins such as sesame and mustard is largely unknown. Furthermore, it is a common clinical scenario for a given individual to outgrow an early milk or egg allergy but not a peanut allergy(5). Therefore it appears that the pathophysiology

(C) 2011 Elsevier Inc. All rights reserved.

Corresponding Author: Brian P. Vickery, M.D., DUMC Box 2644, Durham NC 27710, 919-668-3750 (fax), 919-684-9083 (ph), brian.vickery@duke.edu.

Publisher's Disclaimer: This is a PDF file of an unedited manuscript that has been accepted for publication. As a service to our customers we are providing this early version of the manuscript. The manuscript will undergo copyediting, typesetting, and review of the resulting proof before it is published in its final citable form. Please note that during the production process errors may be discovered which could affect the content, and all legal disclaimers that apply to the journal pertain. 
of food allergy may differ in significant antigen-specific ways even within the same patient. The overrepresentation of peanut and tree nut allergy amongst cases of fatal food anaphylaxis further supports the concept that certain foods tend to be more allergenic than others (6).

However, even though there is significant heterogeneity amongst patients with food allergy, in practice all individuals are considered to be equally sensitive to all foods, and strict avoidance is the standard of care. This is largely due to the inability of standard diagnostic testing to predict a patient's risk for anaphylaxis, or determine an individual's threshold dose to trigger symptoms. Therefore, affected individuals and families maintain a constant state of vigilance to avoid inadvertent exposure to even trace amounts of food allergens; however, even in the most cautious patients, accidental ingestions frequently occur (5). Although fatalities due to accidental ingestions are rare, parents routinely cite a fear of this outcome (7). The inability to completely eliminate the possibility of anaphylaxis and the associated limitations in everyday activities are great sources of uncertainty and stress on affected families. Over time, health-related quality of life is seriously eroded, to a greater degree than seen in other serious chronic diseases of childhood (8).

The gastrointestinal tract, which is the largest immunologic organ in the body, is constantly exposed to an enormous array of exogenous antigens including commensal bacteria and ingested proteins (9). A single epithelial layer separates this antigenic load from the lymphocytes, antigen presenting cells (APC), stromal cells and other immune cells in the lamina propria, which together comprise the mucosal-associated lymphoid tissue (MALT). Within the MALT, unique populations of dendritic cells (DCs) interact with dietary antigens, and determine the fate of the resulting adaptive response, i.e. immunity versus tolerance (10). In this context, immune tolerance is defined as the antigen-specific suppression of cellular or humoral immune responses. When the initial antigen exposure is mediated through the GI tract, a robust $\mathrm{T}$ cell-mediated suppression develops called oral tolerance (11). However, in the $4-6 \%$ of children and $2 \%$ of adults with food allergies, this mechanism appears to fail, and the ensuing immune response proceeds through two phases: allergic sensitization, and elicitation. Allergic sensitization involves $\mathrm{T}$ cell priming after DC activation, and the resultant T-helper- $2\left(\mathrm{~T}_{\mathrm{H}} 2\right)$ response is characterized by the production of interleukin-4 (IL-4), IL-5, and IL-13 from CD4+ T cells. This $\mathrm{T}_{\mathrm{H}} 2$ response leads to B-cell immunoglobulin $\mathrm{E}$ (IgE) production, and this IgE binds to its high-affinity receptor on the surface of mast cells in the skin, gut, respiratory, and cardiovascular systems, arming them for reactivity upon re-exposure to allergen. The elicitation of classic allergic symptoms occurs within minutes after allergen exposure, when IgE-bound mast cells recognize the allergen and become activated (12).

This review will cover the pathophysiology of IgE-mediated food allergy, proceeding through the steps of allergic sensitization and then elicitation. Because most of the mechanistic evidence for the pathophysiology of food allergy and tolerance is derived from experimental animals, we will primarily discuss these model systems. Where possible, we will review the evidence for similar phenomena in human biology and the relevant applications for clinical medicine.

\section{THE INTRINSIC PHYSICAL PROPERTIES OF FOOD ALLERGENS}

The average daily intake of protein in the U.S. diet is approximately 1 gram per kilogram of body weight, and is derived from a great variety of mammals, birds, fish, fungi, and plants. Yet amidst this wide range, only a relatively small number of foods cause the vast majority of food allergies (5). This fact provides an important clue to the underlying pathophysiology of the disease and suggests that these main food allergens - milk, egg, wheat, soy, peanut, 
tree nuts, fish, and crustacea - though diverse in origin, share common characteristics which confer allergenicity. These characteristics include: (1) a relatively small molecular weight, generally < 70 kilo Dalton (kD); (2) an abundant source of the relevant allergen (e.g., the seed storage proteins in nuts which are required to sustain plant growth); (3) glycosylation residues; (4) water solubility; and (5) resistance to heat and digestion. This combination of characteristics is likely unique to food allergens, which unlike inhaled or contact allergens, must pass through the harsh environment of the digestive system, beginning immediately upon entry into the oropharynx. Following ingestion, dietary proteins undergo digestion by enzymes in the saliva and stomach as well as by gastric acid. This processing results in reduced protein immunogenicity, likely by the destruction of conformational epitopes; i.e., antigenic regions formed when non-contiguous amino acids are brought together by the tertiary folded structure of the protein. However, proteins which display the above physicochemical properties resist this processing and thus have allergenic potential upon reaching the small intestine. Additional factors that disrupt normal digestion such as coadministration of antacids have been shown in animal models to result in a breakdown in oral tolerance induction (11).

Because food antigens are non-self proteins, they are recognized as such by the MALT, and as a result all normal individuals mount immune responses to ingested food proteins (12). However, once putative allergens survive the digestion process relatively intact, they must initiate a $\mathrm{T}_{\mathrm{H}} 2$ response in order to result in IgE production and disease expression. There has been a great deal of recent research interest in understanding the cellular and molecular basis of allergenicity, and what intrinsic signals derived from the proteins themselves lead to allergic priming. Whereas the operative allergenic motif has long been considered to be the protein or peptide epitope due to its central importance in $\mathrm{T}$ cell stimulation, recent studies have highlighted the emerging importance of the carbohydrate residues which decorate proteins and influence $\mathrm{T}_{\mathrm{H}} 2$ polarization (13). Studies of inhalant allergens have also identified the intrinsic protease activity of the proteins as well as their molecular resemblance to Toll-like receptor (TLR) ligands (14), but glycosylation appears to play a key role in allergenicity of dietary protein. This is not entirely surprising, given that the mucosal IgE system evolved to defend the host from intestinal metazoan parasites, organisms which are themselves heavily glycosylated.

Shreffler et al demonstrated that the cell-surface receptor Dendritic Cell-Specific Intercellular adhesion molecule-3-Grabbing Non-integrin (DC-SIGN) also known as CD209 DC-SIGN mediates recognition of the major peanut allergen Ara $\mathrm{h} 1$ by human DCs in vitro. DC-SIGN is a c-type lectin expressed on antigen presenting cells (APC) which identifies conserved carbohydrate residues on pathogens and is generally considered to be a component of the innate immune system. Thus the recognition of Ara $\mathrm{h} 1$ by DC-SIGN is dependent on the carbohydrates in the peanut allergens, and furthermore this interaction is sufficient for $\mathrm{DC}$ activation and $\mathrm{T}_{\mathrm{H}} 2$ skewing of naïve human $\mathrm{T}$ cells (15). This may be one example of a broader effect, since other lectins besides DC-SIGN such as the mannose receptor and Dectin-1 and -2 appear to play important roles in recognition of allergens and activation of APCs in murine systems (16). Interestingly, peanut allergens subjected to highheat preparation (i.e. dry roasting) undergo a non-enzymatic glycosylation reaction called the Maillard reaction. This increases the binding of IgE from peanut-allergic subjects and has been hypothesized to partially account for the disproportionate increase in peanut allergy in Westernized societies which consume roasted peanuts, as compared to other cultures with different preparation methods (17). Other major allergens, including those from egg, shrimp, milk, and red meats (as well as dust mite and other inhalant allergens), are also known to be heavily glycosylated. 


\section{THE IMPORTANCE OF TIMING \& DOSE}

Mucosal responses to soluble protein antigens early in life tend to be $\mathrm{T}_{\mathrm{H}} 2$ biased, which has led to the general idea that this occurs by default in both animals and humans (18). Genetics plays a clear role in mouse models, in which certain strains have exaggerated $\mathrm{T}_{\mathrm{H}} 2$ bias whereas others tend to be resistant to sensitization (19), and although family studies suggest a strong genetic component in human food allergy, efforts have largely failed to identify risk alleles (20). More recent evidence supports that impairment in T-reg induction and innate immunity may also contribute to $\mathrm{T}_{\mathrm{H}} 2$ polarization in early life (21). Although these findings might be expected in atopic infants, prospective birth cohort studies have shown that $\operatorname{IgE}$ production to egg, milk, and peanut commonly occur, even in healthy infants (22). Importantly, although there remains some controversy, the inability of recent studies to identify a committed allergen-specific memory $\mathrm{T}_{\mathrm{H}} 2$ response early in life suggests that allergic responses develop postnatally (23). Several studies claimed to present evidence that allergic priming could occur in humans in utero, but these studies have largely been irreproducible, and methodologic flaws in their approach have been identified (24).

In non-allergic individuals, the $\mathrm{T}_{\mathrm{H}} 2$ bias appears to be transient, and IgE levels fall, possibly through a counterbalancing induction of antigen-specific $\mathrm{T}_{\mathrm{H}} 1$ responses (i.e. interferon (IFN)- $\gamma$ ); in contrast, these $\mathrm{T}_{\mathrm{H}} 2$ responses consolidate and strengthen in allergic children, perhaps through induction of IL-4 signaling (24). IL-4 is known to be a key cytokine which acts as a critical step in the allergic cascade, signaling B cells to undergo class-switch recombination and begin producing IgE. A number of cell types produce IL-4, including $\mathrm{T}_{\mathrm{H}} 2$ cells, natural killer $\mathrm{T}$ (NKT) cells, and basophils, and recent mouse studies have implicated basophils as a likely contributor of early IL-4 after allergen exposure (25). Interestingly, in a large cohort of children at high risk for allergy, CD25+ cells expressed significant amounts of IL-4 after stimulation with food allergens, but did not express significant amounts of the $\mathrm{T}_{\mathrm{H}}$ 2-specific transcription factor GATA-3 (26). This indirectly suggests that in humans, a CD25+ non-T cell (i.e. a basophil) may play a role in early allergic sensitization. Identifying the source of IL-4 early in human allergen priming is a key research question.

In mouse models, high-dose exposure to antigen in early life, even a single isolated dose, can produce lymphocyte anergy, whereas low-dose exposure, especially when repeated, induces tolerance through T-reg development (27). Interestingly though, the differences in the actual dosing in these studies is quite small. Emerging evidence in human disease suggests that exposure to the proper dose of antigen during this critical period in early life is important for the shaping of the appropriate immune response to foods. Several epidemiologic studies have implicated delayed weaning patterns in the increased prevalence of peanut allergy $(28,29)$. Similarly there is evidence that delayed introduction of cereals is associated with a higher risk of wheat allergy (30), although methodologic limitations in retrospective studies make definitive conclusions difficult. Recently, European and American guidelines for the introduction of potentially allergenic solid foods were revised to reflect the position that insufficient high-quality evidence exists to support delayed weaning as a preventative (i.e., tolerogenic) strategy $(31,32)$. However, early introduction is not automatically better, since mature immune regulation may require time. In a set of classic experiments, Strobel et al., showed that immunologic priming and allergic sensitization are enhanced in neonatal mouse pups fed the common experimental egg allergen ovalbumin in the first few days of life, whereas tolerance develops only after waiting 7-10 days to introduce antigen (33); if and how this "window" of priming versus tolerance translates to humans is unknown. Cow's milk is typically the first potentially allergenic exposure, often occurring early in life, and yet cow's milk is by far the most common food to which children are allergic (5). Although oral tolerance has been shown to occur across a range of doses, 
frequent or continuous exposure to relatively low doses typically results in robust oral tolerance induction. Defining the most appropriate time and dose for tolerance induction in humans is a great research need. Interventional studies are underway to investigate the importance of early life oral exposure in tolerance development.

\section{ELUDING THE DEFENSES}

As we have seen, specific characteristics intrinsic to food proteins and the details of their exposure are important in determining the potential for inducing a deleterious allergic immune response. However, robust mechanisms exist within the host intestine to prevent would-be allergens from causing harm. The "first-line" features of mucosal defense serve to prevent luminal antigens from interacting with the MALT entirely. These include a hydrophobic layer of mucin oligosaccharides which trap antigen, and both constitutive and inducible antimicrobial peptides. Secretory $\operatorname{IgA}$ has generally been considered to provide important tolerogenic function by binding to luminal antigens and preventing absorption (i.e., "immune exclusion"), although its specific importance has been controversial (34). A recent study showed that mice deficient in the receptor which secretes $\operatorname{IgA}$ and IgM into the intestinal lumen are hypersensitive to IgG-mediated anaphylaxis; nonetheless they can be tolerized by an oral feed prior to systemic priming. In this model, tolerance was transferrable by CD4+CD25+ splenocytes, suggesting that cellular mechanisms can compensate for an impaired immune exclusion mechanism (35). However, a recent case-control study from a larger placebo-controlled trial examining probiotics for allergy prevention in high risk infants showed that the risk of atopy was inversely correlated with fecal IgA levels (36). These data serve as one example of the complex and complementary forces which act to suppress immunity in the gut.

If a potential allergen penetrates these first few physical factors, the intestinal epithelium itself acts as a barrier to sequester luminal antigens from the MALT, and leakiness of this barrier has been postulated to result in allergic sensitization. Structural integrity of the intestinal epithelium is conferred by epithelial junction complexes, also called adherens junctions, and tight junctions. However, it may take years for complete developmental maturation of the gut barrier in healthy children (37). In mice, the permeability of this barrier is further influenced by exposures to microbial pathogens such as viruses, alcohol, non-steroid anti-inflammatory drugs (NSAIDs), and other toxins, as well as cytokines such as IL-9, immune cells and apoptotic pathways. These environmental exposures ultimately result in changes in gene expression and phosphorylation of tight junction proteins such as occludins, claudins, and JAM-ZO1 proteins, which in turn are associated with changes in intestinal mast cells and allergic sensitization $(38,39)$.

Interestingly, intestinal permeability was assessed in food-allergic infants by examining the lactulose/mannitol ratio in urine, and these infants were noted to have increased intestinal permeability when compared with normal healthy young children (40). Investigators examined this ratio in children who had been on an allergen-free diet for at least 6 months and determined that intestinal permeability remained increased in food-allergic children, despite the absence of food allergen stimulation. Further evidence linking intestinal epithelial barrier dysfunction and food allergy comes from studies in immunosuppressed humans after solid-organ transplantation, who developed food allergy while on calcineurin inhibitors. Initially, investigators assumed this allergy was the result of transfer of sensitized donor lymphocytes. However, it is now theorized that medication-induced decreases in cellular Adenosine triphosphate (ATP) levels altered the integrity of junctional complexes, resulting in increased intestinal permeability (41). Mutations in the gene encoding filaggrin also lead to profound epidermal barrier dysfunction and are highly prevalent in atopic dermatitis patients, which is in turn associated with an increased prevalence of food allergy. 
Acquired barrier defects associated with decreased filaggrin expression have been observed in the esophagus of patients with eosinophilic esophagitis, and are thought to be downregulated secondary to IL-13 (42). However, no studies to date have examined the mechanistic relationship of filaggrin mutations to IgE priming in the gut or clinical food allergy (43).

Increasing evidence suggests that the mucosal epithelium is likely to play an active role in determining the host response to food allergens, which goes far beyond simply acting as an inert physical barrier. Epithelial cells are known to express major histocompatibility complex (MHC) class II molecules on their basolateral membranes and thus may act as nonprofessional APCs which do not express conventional co-stimulatory molecules, favoring anergy or tolerance (44). In addition, factors derived from the gut epithelium are generally believed to condition the DCs in the stroma, dampening immune responses and promoting gut homeostasis (45). One such factor, constitutively expressed by the gut epithelium, is thymic stromal lymphopoetin (TSLP). TSLP is an IL-7 like cytokine which has been shown to activate expression of OX40L on dendritic cells and drive $\mathrm{T}_{\mathrm{H}} 2$ differentiation. Thus, TSLP is a critical mediator of allergic inflammation in the lung and skin. By contrast, in the gut, TSLP appears to play a regulatory role, limiting deleterious $\mathrm{T}_{\mathrm{H}} 1$ and $\mathrm{T}_{\mathrm{H}} 17$ inflammation in models of helminth infection and colitis (46). Although incompletely understood, this regulation may occur at the level of the DC, which expresses the TSLP receptor and has been shown to develop tolerogenic properties after TSLP exposure. Interestingly, regulatory responses to dietary allergens are evidently normal in TSLP receptor-deficient animals (47). These findings suggest that though allergic sensitization in the gut may be mediated or regulated via TSLP, it is not required for oral tolerance. Little is known about the role of TSLP in food sensitization in humans. However, a recent study identified TSLP gene expression in the esophagus of patients with eosinophilic esophagitis and showed that genetic variants in TSLP and the TSLP receptor are associated with the disease (48).

\section{THE MICROBIOME: FRIEND OR FOE?}

Another critical influence on the gastrointestinal mucosal immune response is the microbial stimulation provided by the enteric flora, which by adulthood number approximately 100 trillion in the large intestine, providing essential nutritional and immunologic benefits (49). These bacteria colonize the neonatal GI tract and begin interacting with the MALT within hours of birth. This interaction probably represents the primary stimulus for proper postnatal immune development, since germ-free mice, which are not colonized with bacteria at birth, have disorganized and poorly developed mucosal and secondary lymphoid structures. In the absence of a microbial flora, these animals have impaired antibody responses and do not develop oral tolerance (50). In humans, specific differences have been identified in the flora of allergic and non-allergic children (51). This suggests that although intestinal microbial colonization is required for proper immune development, certain microbes may play a significant role in skewing the immune response towards allergic sensitization. Exactly how this may occur is almost completely unknown.

The critical information provided by the microbiome is interpreted through signals from innate immune receptors such as TLRs, which play an important role in intestinal homeostasis (52), in the genesis of T-regs (53), and on the outcome of allergic disease (54). Most food allergy studies in mice use the $\mathrm{C} 3 \mathrm{H} / \mathrm{HeJ}$ strain, which cannot signal through TLR4, implicating the importance of its signal in promoting tolerance. Investigators have identified specific microbial products (i.e. polysaccharide A from Bacteroides fragilis) which interact with TLRs and promote downstream induction of T-regs, which subsequently modulate intestinal inflammation in mouse models of experimental colitis (53). However, 
determining the specific microbial signal(s) which is/are most critical in determining whether a response to a food protein will be allergic or toleragenic in humans has proven challenging, as evidenced by the overall disappointing results of probiotic trials on prevention and treatment of allergic disease (55). This difficulty may be largely technical, because historically most studies have relied on culture-based methods to attempt to identify an incredibly diverse ecosystem, of which many members are fastidious or simply unculturable. New deep-sequencing technologies which focus on the unique 16s ribosomal subunit of bacterial RNA allow investigators to identify previously unknown organisms and promise to revolutionize our understanding of these critical microbes (56). Coupling 16s rRNA sequencing techniques with high-throughput approaches allows profiling of entire bacterial communities, forming the basis of the Human Microbiome Project (HMP) to characterize the entire flora (http://nihroadmap.nih.gov/hmp/). Traditional culture-based techniques have already succeeded at identifying differences in the flora of allergic versus healthy children, and the HMP will undoubtedly shed important new light on this critical influence. If so, this will uncover new therapeutic targets to prevent or treat allergic sensitization, possibly with clinically available antimicrobial and/or pro- or pre-biotic approaches.

\section{ANTIGEN-PRESENTING CELLS SET THE STAGE}

Should allergenic food proteins survive oral and gastric digestion and evade luminal defenses, they will be detected by APCs in the MALT, likely in the context of signals provided by the commensal flora. In this way, a complex interplay of all aforementioned factors (i.e., antigen character, dose, timing, and innate immune stimulation) will determine the immune response to an ingested food protein through the same final common pathway: by directly or indirectly influencing the APC. Much recent research has begun to demonstrate that mucosal DCs are probably the most critical determinant of allergic sensitization versus tolerance in naïve individuals, largely because of their location and their capacity to receive and interpret environmental signals, which lead to a specific immune response. These DCs can encounter ingested antigen in one of three ways: by extending dendrites through the paracellular space between epithelial cells to sample luminal contents, by directly interacting with the epithelial cells, and by taking up antigen in the Peyer patch, specialized lymphoid tissue which is immediately adjacent to microfold cells (57). The properties of the antigen itself - particulate versus soluble - to a certain extent determine the route of exposure, and it is likely that each route will involve distinct DC populations.

The traditional paradigm for initiation of an immune response involves an APC encountering an antigen in the periphery and then migrating to the local lymph node to interact with T cells. Although macrophages, B cells, and others can act as APCs, DCs are generally considered to be "professional" APCs which excel at the required functions. In their immature state, DCs sample their local environment and become activated when they encounter antigen in the context of microbial stimulation. This typically results in antigen processing, loading of the processed peptide antigen onto MHC class II molecules on the cell surface, upregulation of the co-stimulatory molecules necessary for T cell stimulation, and chemotaxis to the draining lymph node. There, activated DCs interact with many $\mathrm{T}$ cells, and when they encounter a $\mathrm{T}$ cell which expresses a $\mathrm{T}$ cell receptor (TCR) with the same specificity as the peptide antigen in the DC's class II molecule, an immune response ensues. When this DC-T cell interaction occurs in the appropriate milieu (i.e., significant amounts of IL-4,-5, and -13), the responding $\mathrm{T}$ cell is programmed to be $\mathrm{T}_{\mathrm{H}} 2$ cell, which can then signal B cells to generate IgE antibody. In this way, the allergic response is perpetuated. How this pro-allergic initial milieu is developed (a.k.a. the "original sin") in a naïve individual remains a fundamental question. There is some evidence in animals that basophils may contribute an early supply of IL-4, along with pro-allergic TSLP (58). As 
described above, recognition of carbohydrates by lectins may also provide key signals to DCs which drive $\mathrm{T}_{\mathrm{H}} 2$ polarization.

Many features combine to make the intestine a unique immunologic situation, and the traditional paradigm described above may not hold. For example, there is now evidence that IgE may be produced locally at the mucosal surface of the intestine, as it is in other mucosal sites like the respiratory tract $(59,12)$. The physical address of the DC-T cell interaction described above appears to be critical in determining the type of immune response that ensues. The lamina propria, which is full of lymphocytes, and the Peyer patches function as lymphoid structures, and are sufficient for induction of local immune responses. Several specialized APC populations reside within this loosely organized network and receive important signals from the epithelium and other adjacent structures. In this way, the local microenvironment provides key information to a specialized APC and influences an appropriate immune response; this likely represents a robust evolutionary adaptation to the rich antigenic environment in the gut. The health of the host depends on intestinal homeostasis, and careful recent studies in mice have highlighted the critical importance of the mesenteric lymph node (MLN) in preserving a state of non responsiveness. Whereas immunity can be generated locally, tolerance appears to depend upon the migration, guided by the chemokine receptor CCR7, of pro-toleragenic DCs to the MLN. A key distinguishing feature of these pro-toleragenic DCs is the expression of the marker CD103 (60). By contrast, CD103-negative lamina propria DCs are strongly pro-inflammatory. These data suggest that tolerogenic DCs may receive site-specific signals from the intestinal epithelium through interactions with E-cadherin, a ligand of CD103; it is likely that local signals generated by the epithelium provide a unique microenvironment which licenses antigen presentation towards appropriate inflammatory versus tolerogenic outcomes (61). Other local factors which play important roles in this complex interaction include the vitamin A analogue retinoic acid and the immunosuppressive cytokine transforming growth factor-beta (TGF- $\beta$ ), both of which tend to induce tolerance (62). The importance of CD103 expression and retinoic acid in regulating intestinal immune responses have also been shown in humans, implicating them as potential therapeutic targets to minimize adverse immune responses such as food allergy.

\section{T CELLS PROMOTE ALLERGIC INFLAMMATION}

At this point, the putative allergen has survived the passage into the intestine, been processed into a peptide and presented on the cell surface of an APC in the binding groove of the MHC II molecule, and then recognized by a TCR. This TCR-MHC interaction provides the first of three signals required for $\mathrm{T}$ cell activation. The second is provided by the interaction of the co-stimulatory molecules CD80 and CD86 on the surface of the APC with CD28 on the surface of the T cell. The third is the signal provided by cytokines, which in the case of allergic immune responses are IL-4, IL-5, and IL-13. These three signals activate the $\mathrm{T}$ cell and cause up-regulation of the transcription factor GATA-3, which is necessary and sufficient for $\mathrm{T}_{\mathrm{H}} 2$ differentiation. This $\mathrm{T}_{\mathrm{H}} 2 \mathrm{~T}$ cell can then amplify the $\mathrm{T}_{\mathrm{H}} 2$ cytokine response and proliferate, which results in growth and division of cells with identical specificity (i.e. clonal expansion). Whereas many of these expanded $\mathrm{T}_{\mathrm{H}} 2$ cells will eventually undergo apoptosis, some will further differentiate into memory $\mathrm{T}$ cells, which maintain strong $\mathrm{T}_{\mathrm{H}} 2$ bias and serve to perpetuate allergic responses (63). This is a critical step in the development of long-term immune memory, which can occur in patients with chronic allergy. An example is peanut allergy, which in contrast to egg or milk allergy, is not commonly outgrown (64). It is not well understood why some allergies naturally resolve and others persist, but it is generally believed to be under the control of specialized T cells (i.e. regulatory $\mathrm{T}$ cells) which can shut off the $\mathrm{T}_{\mathrm{H}} 2$ response. 
Newly differentiated $\mathrm{T}_{\mathrm{H}} 2$ cells also serve one other important purpose: providing $\mathrm{T}$ cell help to B cells.

\section{B CELLS: IgE FACTORIES}

In contrast to the $\mathrm{T}$ cell, which expresses the TCR, the antigen receptor expressed on the surface of a B cell is an immunoglobulin. B cells can thus bind allergen and interact with a $\mathrm{CD} 4+\mathrm{T}$ cell which has specificity for the same allergen. When this occurs, the helper $\mathrm{T}$ cell signals the B cell to undergo antibody production. In the context of allergen presentation, IL-4 produced by the $\mathrm{T}_{\mathrm{H}} 2$ cell, as well as the interaction of CD40 ligand on the $\mathrm{T}$ cell surface with CD40 on the B cell surface, cause the B cells to undergo class switch recombination and begin making IgE. All of the previously described events culminate here in allergic sensitization, defined as the production of allergen-specific IgE antibodies (65). Sensitization is a critical step in the pathophysiology of food allergy, because classical food reactions are IgE-mediated and involve symptoms characteristic of type 1 hypersensitivity such as urticaria, angioedema, and anaphylaxis. However, it is extremely important to note that sensitization is necessary but not sufficient for the expression of clinical allergy. In other words, many healthy individuals will produce $\operatorname{IgE}$ antibodies to foods which they clinically tolerate; therefore, the presence of IgE can only be interpreted as a likely allergy in the context of a history which supports a pathologic role for that antibody (66). This can be thought of as analogous to a positive Purified Protein Derivative (PPD) test, which only confirms exposure to Mycobacteria. The diagnosis of tuberculosis depends on a fitting clinical history (hemoptysis, weight loss, night sweats, cavitary lung lesions, etc). Although the gold standard diagnostic test for food allergy is an oral food challenge, in patients with a suggestive history, high titers of food-specific IgE have been shown to be associated with a high enough probability of food allergy that challenge is not necessary (67).

The IgE secreted by the B cell has the same specificity as the immunoglobulin expressed on the surface of the B cell (i.e. it is clonal). Although IgE is by far the least prevalent antibody isotype in the circulation, allergen-specific IgE is readily detectable by both standard allergy skin prick tests as well as in vitro immunoassays. In standard allergy tests, the $\mathrm{IgE}$ is detected using whole allergen, and the exact epitope specificity of the IgE is unknown. However, because food allergens are large macromolecules, they will typically activate multiple B cells in vivo and thus generate polyclonal $\mathrm{IgE}$ responses which have diverse specificities. Several recent studies of patients allergic to egg, peanut, shrimp, and milk have shown that the binding patterns of $\operatorname{IgE}$, and in some cases the recognition of specific amino acid sequences within the allergen, are correlated with both the persistence and the severity of the allergy (68). The IgE repertoire has been shown to be stable over the course of years in peanut allergy patients (69), suggesting that they are being produced by either memory B cells or perhaps long-lived plasma cells which have differentiated from B cells. It remains poorly understood how and why patients with persistent food allergy continue to make high titers of highly pathogenic antibodies in the absence of any exposure to antigen. Conversely, in children who do "outgrow" food allergy, a sustained reduction in IgE levels typically heralds the development of spontaneous clinical tolerance. Identifying the mechanisms which regulate IgE production in allergic humans is thus a critical research goal.

\section{ELICITATION: MAST CELLS}

The soluble IgE which is produced by B cells circulates and binds to the surface of mast cells and basophils, arming them for reactivity and completing a key step in the pathophysiology of allergic reactions. Mast cells are unique, highly granulated, tissueresident cells which are increasingly recognized for a diversity of immune functions. They are found in the skin, gut, respiratory tract, and are situated adjacent to nerves and blood 
vessels. Among the most important of their immune functions is the propensity to bind $\operatorname{IgE}$ utilizing the high-affinity IgE receptor FceR1. When allergen is re-encountered and recognized by cell-bound IgE, adjacent Fc\&R1-IgE complexes move closer together and bring their signaling machinery into close proximity, which sets off a cascade of phosphorylation, ultimately resulting in calcium influx. When calcium enters the cell, the activated mast cell undergoes degranulation, and the contents of these granules are released into the extracellular space. The immediate liberation of preformed powerful vasoactive compounds such as histamine, platelet activating factor, tryptase, carboxypeptidase, chymase, and heparin elicit the acute symptoms of type 1 hypersensitivity reactions in the skin, gut, respiratory, and cardiovascular systems (70). These symptoms include urticaria, angioedema, flushing, nausea, vomiting, abdominal pain, diarrhea, wheezing, coughing/ bronchospasm, rhinorrhea, and hypotension / syncope, which can occur alone or in combination, and typically begin within minutes of food ingestion. Tryptase is not uniformly elevated in food anaphylaxis, leading some to question whether basophils play a larger role than do mast cells in human food anaphylaxis; however, there is little direct evidence of their involvement. Mast cells also synthesize other mediators such as cysteinyl leukotrienes and prostaglandins upon activation, which require several hours to achieve their inflammatory effects, including recruitment and activation of secondary immune cells such as eosinophils.

\section{CONCLUSIONS}

Although food allergy affects 12 million Americans, it is remarkable that it is not more common considering the complexities of the mucosal immune system. Robust immunologic mechanisms involving both humoral and cell-mediated responses have evolved to maintain a homeostatic environment amidst the literally billions of antigens within the intestine. In order to incite the allergic cascade, an ingested protein must circumvent this tolerogenic system. The sensitization phase begins when certain physicochemical characteristics increase the allergenicity of dietary proteins. Their capture by inflammatory dendritic cells in the gut results in an active immune response, which occurs under the influence of the local microenvironment. Certain key signals such as IL-4 lead to $\mathrm{T}_{\mathrm{H}} 2$ differentiation and propagation of the allergic $\mathrm{T}$ cell response as well as isotype switching and $\operatorname{IgE}$ production. This allergen-specific IgE binds to the surface of mast cells and elicits mediator release within minutes to an hour after re-exposure to the allergen. Bioactive mediators released by mast cells act on endothelium, smooth muscle, and epithelium to produce the symptoms characteristic of allergic reactions.

\section{Acknowledgments}

Funding Source:

Food Allergy \& Anaphylaxis Network; Food Allergy Project; Gerber Foundation; NIH Grant 1 R01AI06874-01A1, NIH T32 Training Grant, and NIH Grant 1 UL1 RR024128-01 from the National Center for Research Resources (NCRR), a component of the National Institutes of Health (NIH) and NIH Roadmap for Medical Research (contents are solely the responsibility of the authors and do not necessarily represent the official view of NCRR or NIH); and the National Peanut Board.

\section{REFERENCES}

1. Chafen JJS, Newberry SJ, Riedl MA, Bravata DM, Maglione M, Suttorp MJ, et al. Diagnosing and Managing Common Food Allergies: A Systematic Review. JAMA. May 12; 2010 303(18):18481856. [PubMed: 20460624]

2. Branum AM, Lukacs SL. Food Allergy Among Children in the United States. Pediatrics. Dec 1; 2009 124(6):1549-1555. [PubMed: 19917585] 
3. Venter C, Arshad SH, Grundy J, Pereira B, Clayton CB, Voigt K, et al. Time trends in the prevalence of peanut allergy: three cohorts of children from the same geographical location in the UK. Allergy. 2010; 65(1):103-108. [PubMed: 20078504]

4. Gupta R, Sheikh A, Strachan DP, Anderson HR. Time trends in allergic disorders in the UK. Thorax. Jan; 2007 62(1):91-96. [PubMed: 16950836]

5. Sicherer SH, Sampson HA. Food allergy. J Allergy Clin Immunol. Feb; 2010 125(2, Supplement 2):S116-S125. [PubMed: 20042231]

6. Bock SA, Munoz-Furlong A, Sampson HA. Further fatalities caused by anaphylactic reactions to food, 2001-2006. J Allergy Clin Immunol. 2007; 119:1016-1018. [PubMed: 17306354]

7. Gupta RS, Springston EE, Smith B, Kim JS, Pongracic JA, Wang X, Holl J. Food allergy knowledge, attitudes, and beliefs of parents with food-allergic children in the United States. Pediatr Allergy Immunol. Sep; 2010 21(6):927-34. Epub 2010 May 14. [PubMed: 20492544]

8. Cummings AJ, Knibb RC, King RM, Lucas JS. The psychosocial impact of food allergy and food hypersensitivity in children, adolescents and their families: a review. Allergy. 2010; 65(8):933-945. [PubMed: 20180792]

9. Chehade M, Mayer L. Oral tolerance and its relation to food hypersensitivities. J Allergy Clin Immunol. 2005; 115(1):3-12. [PubMed: 15637539]

10. Coombes JL, Powrie F. Dendritic cells in intestinal immune regulation. Nat Rev Immunol. Jun; 2008 8(6):435-446. [PubMed: 18500229]

11. Faria AMC, Weiner HL. Oral tolerance. Immunol Rev. 2005; 206(1):232-259. [PubMed: 16048553]

12. Gould HJ, Sutton BJ. IgE in allergy and asthma today. Nat Rev Immunol. Mar; 2008 8(3):205-17. [PubMed: 18301424]

11. Untersmayr E, Jensen-Jarolim E. The role of protein digestibility and antacids on food allergy outcomes. J Allergy Clin Immunol. Jun; 2008 121(6):1301-1308. [PubMed: 18539189]

12. Husby S, Oxelius VA, Teisner B, Jensenius JC, Svehag SE. Humoral immunity to dietary antigens in healthy adults. Occurrence, isotype and $\mathrm{IgG}$ subclass distribution of serum antibodies to protein antigens. Int Arch Allergy Appl Immunol. 1985; 77(4):416-22. [PubMed: 4018884]

13. Berin MC, Shreffler WG. T(H)2 adjuvants: implications for food allergy. J Allergy Clin Immunol. Jun; 2008 121(6):1311-20. [PubMed: 18539190]

14. Karp CL. Guilt by intimate association: what makes an allergen an allergen? J Allergy Clin Immunol. May; 2010 125(5):955-60. [PubMed: 20381850]

15. Shreffler WG, Castro RR, Kucuk ZY, Charlop-Powers Z, Grishina G, Yoo S, Burks AW, Sampson HA. The major glycoprotein allergen from Arachis hypogaea, Ara h 1,is a ligand of dendritic cellspecific ICAM-grabbing nonintegrin and acts as a Th2 adjuvant in vitro. J Immunol. Sep 15; 2006 177(6):3677-85. [PubMed: 16951327]

16. Wills-Karp M, Nathan A, Page K, Karp CL. New insights into innate immune mechanisms underlying allergenicity. Mucosal Immunol. Mar; 2010 3(2):104-10. [PubMed: 20032970]

17. Nowak-Wegrzyn A, Fiocchi A. Rare, medium, or well done? The effect of heating and food matrix on food protein allergenicity. Curr Opin Allergy Clin Immunol. Jun; 2009 9(3):234-7. [PubMed: 19444093]

18. Weiner HL, Friedman A, Miller A, Khoury SJ, Al-Sabbagh A, Santos L, et al. Oral Tolerance: Immunologic Mechanisms and Treatment of Animal and Human Organ-Specific Autoimmune Diseases by Oral Administration of Autoantigens. Ann Rev Immunol. Apr 1; 1994 12(1):809-837. [PubMed: 8011298]

19. Berin MC, Zheng Y, Domaradzki M, Li XM, Sampson HA. Role of TLR4 in allergic sensitization to food proteins in mice. Allergy. 2006; 61(1):64-71. [PubMed: 16364158]

20. Hong X, Tsai HJ, Wang X. Genetics of food allergy. Curr Opin Pediatr. Dec; 2009 21(6):770-6. [PubMed: 19851108]

21. Prescott SL. Allergic disease: understanding how in utero events set the scene. Proc Nutr Soc. 2010; 69(03):366-372. [PubMed: 20587128]

22. Sigurs N, Hattevig G, Kjellman B, Kjellman NM, Nilsson L, Bjorksten B. Appearance of atopic disease in relation to serum $\mathrm{IgE}$ antibodies in children followed up from birth for 4 to 15 years. $\mathrm{J}$ Allergy Clin Immunol. Oct; 1994 94(4):757-763. [PubMed: 7930310] 
23. Rowe J, Kusel M, Holt BJ, Suriyaarachchi D, Serralha M, Hollams E, Yerkovich ST, Subrata LS, Ladyman C, Sadowska A, Gillett J, Fisher E, Loh R, Soderstrom L, Ahlstedt S, Sly PD, Holt PG. Prenatal versus postnatal sensitization to environmental allergens in a high-risk birth cohort. J Allergy Clin Immunol. May; 2007 119(5):1164-73. [PubMed: 17412403]

24. Holt PG. Prenatal versus postnatal priming of allergen specific immunologic memory: The debate continues. J Allergy Clin Immunol. Oct; 2008 122(4):717-718. [PubMed: 19014763]

25. Paul WE, Zhu J. How are T(H)2-type immune responses initiated and amplified? Nat Rev Immunol. Apr; 2010 10(4):225-35. [PubMed: 20336151]

26. Sicherer SH, Wood RA, Stablein D, Burks AW, Liu AH, Jones SM, Fleischer DM, Leung DY, Grishin A, Mayer L, Shreffler W, Lindblad R, Sampson HA. Immunologic features of infants with milk or egg allergy enrolled in an observational study(Consortium of Food Allergy Research) of food allergy. J Allergy Clin Immunol. May; 2010 125(5):1077-1083.e8. [PubMed: 20451041]

27. Burks AW, Laubach S, Jones SM. Oral tolerance, food allergy, and immunotherapy: Implications for future treatment. J Allergy Clin Immunol. Jun; 2008 121(6):1344-1350. [PubMed: 18410959]

28. Du Toit G, Katz Y, Sasieni P, Mesher D, Maleki SJ, Fisher HR, et al. Early consumption of peanuts in infancy is associated with a low prevalence of peanut allergy. $\mathrm{J}$ Allergy Clin Immunol. Nov; 2008 122(5):984-991. [PubMed: 19000582]

29. Fox AT, Sasieni P, du Toit G, Syed H, Lack G. Household peanut consumption as a risk factor for the development of peanut allergy. J Allergy Clin Immunol. Feb; 2009 123(2):417-423. [PubMed: 19203660]

30. Poole JA, Barriga K, Leung DY, Hoffman M, Eisenbarth GS, Rewers M, et al. Timing of Initial Exposure to Cereal Grains and the Risk of Wheat Allergy. Pediatrics. Jun 1; 2006 117(6):21752182. [PubMed: 16740862]

31. Greer FR, Sicherer SH, Burks A. Effects of Early Nutritional Interventions on the Development of Atopic Disease in Infants and Children: The Role of Maternal Dietary Restriction, Breastfeeding, Timing of Introduction of Complementary Foods, and Hydrolyzed Formulas. Pediatrics. 2008; 121(1):183-91. [PubMed: 18166574]

32. Høst A, Halken S, Muraro A, Dreborg S, Niggemann B, Aalberse R, et al. Dietary prevention of allergic diseases in infants and small children. Pediatr Allergy Immunol. 2008; 19(1):1-4.

33. Strobel S, Ferguson A. Immune Responses to Fed Protein Antigens in Mice. 3. Systemic Tolerance or Priming Is Related to Age at Which Antigen Is First Encountered. Pediatr Res. 1984; 18(7)

34. Brandtzaeg P. Update on mucosal immunoglobulin A in gastrointestinal disease. Curr Opin Gastro. :9000. Publish Ahead of Print. Available from: http://journals.lww.com/ cogastroenterology/Fulltext/publishahead/Update_on_mucosal_immunoglobulin_A_in. 99878.aspx.

35. Karlsson MR, Johansen F, Kahu H, Macpherson A, Brandtzaeg P. Hypersensitivity and oral tolerance in the absence of a secretory immune system. Allergy. 2010; 65(5):561-570. [PubMed: 19886928]

36. Kukkonen K, Kuitunen M, Haahtela T, Korpela R, Poussa T, Savilahti E. High intestinal IgA associates with reduced risk of IgE-associated allergic diseases. Pediatr Allergy Immunol. 2010; 21(1-Part-I):67-73. [PubMed: 19566584]

37. Dahan S, Roth-Walter F, Arnaboldi P, Agarwal S, Mayer L. Epithelia: lymphocyte interactions in the gut. Immunol Rev. 2007; 215(1):243-253. [PubMed: 17291293]

38. Forbes EE, Groschwitz K, Abonia JP, Brandt EB, Cohen E, Blanchard C, et al. IL-9- and mast cell-mediated intestinal permeability predisposes to oral antigen hypersensitivity. J Exp Med. Apr 14; 2008 205(4):897-913. [PubMed: 18378796]

39. Groschwitz KR, Hogan SP. Intestinal barrier function: Molecular regulation and disease pathogenesis. J Allergy Clin Immunol. Jul; 2009 124(1):3-20. [PubMed: 19560575]

40. Ventura M, Polimeno L, Amoruso A, Gatti F, Annoscia E, Marinaro M, et al. Intestinal permeability in patients with adverse reactions to food. Dig Liver Dis. Oct; 2006 38(10):732-736. [PubMed: 16880015]

41. Levy Y, Davidovits M, Cleper R, Shapiro R. New-onset post-transplantation food allergy in children - Is it attributable only to the immunosuppressive protocol? Pediatr Transplant. Feb; 2009 13(1):63-69. [PubMed: 18179638] 
42. Blanchard C, Stucke EM, Burwinkel K, Caldwell JM, Collins MH, Ahrens A, et al. Coordinate Interaction between IL-13 and Epithelial Differentiation Cluster Genes in Eosinophilic Esophagitis. J Immunol. Apr 1; 2010 184(7):4033-4041. [PubMed: 20208004]

43. van den Oord R, Sheikh A. Filaggrin gene defects and risk of developing allergic sensitisation and allergic disorders: systematic review and meta-analysis. BMJ. 339:b2243.

44. Hershberg RM, Cho DH, Youakim A, Bradley MB, Lee JS, Framson PE, et al. Highly polarized HLA class II antigen processing and presentation by human intestinal epithelial cells. J Clin Invest. 1998; 102(4):792-803. [PubMed: 9710448]

45. Iliev ID, Matteoli G, Rescigno M. The yin and yang of intestinal epithelial cells in controlling dendritic cell function. J Exp Med. 2007; 204(10):2253-7. [PubMed: 17893197]

46. Ziegler SF, Artis D. Sensing the outside world: TSLP regulates barrier immunity. Nat Immunol. Apr; 2010 11(4):289-293. [PubMed: 20300138]

47. Blazquez AB, Berin MC. Gastrointestinal Dendritic Cells Promote Th2 Skewing via OX40L. J Immunol. 2008; 180(7):4441-50. [PubMed: 18354165]

48. Sherrill JD, Gao P, Stucke EM, Blanchard C, Collins MH, Putnam PE, et al. Variants of thymic stromal lymphopoietin and its receptor associate with eosinophilic esophagitis. J Allergy Clin Immunol. Jul; 2010 126(1):160-165.e3. [PubMed: 20620568]

49. Round JL, Mazmanian SK. The gut microbiota shapes intestinal immune responses during health and disease. Nat Rev Immunol. May; 2009 9(5):313-323. [PubMed: 19343057]

50. Mowat A, Parker L, Beacock-Sharp H, Millington OR, Chirdo F. Oral tolerance: overview and historical perspectives. Ann NY Acad Sci. 2004; 1029:1-8. 1 Oral Tolerance: New Insights and Prospects for Clinical Application. [PubMed: 15806729]

51. Bjorksten B, Sepp E, Julge K, Voor T, Mikelsaar M. Allergy development and the intestinal microflora during the first year of life. J Allergy Clin Immunol. Oct; 2001 108(4):516-520. [PubMed: 11590374]

52. Rakoff-Nahoum S, Paglino J, Eslami-Varzaneh F, Edberg S, Medzhitov R. Recognition of commensal microflora by Toll-like receptors is required for intestinal homeostasis. Cell. 2004; 118:229-241. [PubMed: 15260992]

53. Round JL, Mazmanian SK. Inducible Foxp3+ regulatory T-cell development by a commensal bacterium of the intestinal microbiota. Proc Nat Acad Sci. Jul 6; 2010 107(27):12204-12209. [PubMed: 20566854]

54. Holt PG, Strickland DH. Soothing signals: transplacental transmission of resistance to asthma and allergy. J Exp Med. Dec 21; 2009 206(13):2861-2864. [PubMed: 19995954]

55. Yao T, Chang C, Hsu Y, Huang J. Review Article: Probiotics for allergic diseases: Realities and myths. Pediatr Allergy Immunol. 2010; 21(6):900-919. [PubMed: 20003066]

56. Medini D, Serruto D, Parkhill J, Relman DA, Donati C, Moxon R, et al. Microbiology in the postgenomic era. Nat Rev Micro. Jun; 2008 6(6):419-430.

57. Mowat AM. Anatomical basis of tolerance and immunity to intestinal antigens. Nat Rev Immunol. 2003; 3(4):331-341. [PubMed: 12669023]

58. Sokol CL, Medzhitov R. Emerging functions of basophils in protective and allergic immune responses. Mucosal Immunol. Mar; 2010 3(2):129-37. [PubMed: 20072123]

59. Coëffier M, Lorentz A, Manns MP, Bischoff SC. Epsilon germ-line and IL-4 transcripts are expressed in human intestinal mucosa and enhanced in patients with food allergy. Allergy. Jun; 2005 60(6):822-7. [PubMed: 15876314]

60. Worbs T, Bode U, Yan S, Hoffmann MW, Hintzen G, Bernhardt G, et al. Oral tolerance originates in the intestinal immune system and relies on antigen carriage by dendritic cells. J. Exp. Med. Mar 20; 2006 203(3):519-527. [PubMed: 16533884]

61. Belkaid Y, Oldenhove G. Tuning Microenvironments: Induction of Regulatory T Cells by Dendritic Cells. Immunity. Sep 19; 2008 29(3):362-371. [PubMed: 18799144]

62. Mucida, D.; Park, Y.; Cheroutre, H. From the diet to the nucleus: Vitamin A and TGF- $\beta$ join efforts at the mucosal interface of the intestine; Seminars in Immunology; Elsevier. 2009; p. 14-21.

63. Galli SJ, Tsai M, Piliponsky AM. The development of allergic inflammation. Nature. Jul 24; 2008 454(7203):445-54. [PubMed: 18650915] 
64. Flinterman AE, Pasmans SG, den Hartog Jager CF, Hoekstra MO, Bruijnzeel-Koomen CA, Knol EF, van Hoffen E. T cell responses to major peanut allergens in children with and without peanut allergy. Clin Exp Allergy. Apr; 2010 40(4):590-7. [PubMed: 20067479]

65. Geha RS, Jabara HH, Brodeur SR. The regulation of immunoglobulin E class-switch recombination. Nat Rev Immunol. Sep; 2003 3(9):721-32. [PubMed: 12949496]

66. Du Toit G, Santos A, Roberts G, Fox AT, Smith P, Lack G. The diagnosis of IgE-mediated food allergy in childhood. Pediatr Allergy Immunol. Jun; 2009 20(4):309-19. [PubMed: 19538353]

67. Sampson HA. Utility of food-specific IgE concentrations in predicting symptomatic food allergy. J Allergy Clin Immunol. May; 2001 107(5):891-6. [PubMed: 11344358]

68. Lin J, Sampson HA. The role of immunoglobulin E-binding epitopes in the characterization of food allergy. Curr Opin Allergy Clin Immunol. Aug; 2009 9(4):357-63. [PubMed: 19568005]

69. Shreffler WG, Beyer K, Chu TH, Burks AW, Sampson HA. Microarray immunoassay: association of clinical history, in vitro $\operatorname{IgE}$ function, and heterogeneity of allergenic peanut epitopes. J Allergy Clin Immunol. Apr; 2004 113(4):776-82. [PubMed: 15100687]

70. Galli SJ, Tsai M. Mast cells in allergy and infection: versatile effector and regulatory cells in innate and adaptive immunity. Eur J Immunol. Jul; 2010 40(7):1843-51. [PubMed: 20583030] 